\title{
Urgent Transition to Group Online Foreign Language Instruction: Problems and Solutions
}

\author{
Daria V. Kolesova, Leonid V. Moskovkin and Tatiana I. Popova \\ St. Petersburg State University, Russian Federation \\ d.kolesova@spbu.ru \\ l.moskovkin@spbu.ru \\ t.popova@spbu.ru
}

\begin{abstract}
The purpose of this work is to study how teachers and students react to the urgent large-scale transition to online education. The research was done via surveys conducted at the Center for Additional Educational Programs in the field of Russian as a Foreign Language at St. Petersburg State University. March 2020 transition to distance learning kept intact the lesson schedule, the duration of lessons, and the compliance with the approved programs. This case study was conducted as follows: (1) a questionnaire for teachers was distributed via e-mail; (2) teachers' responses were collected and processed; (3) a questionnaire for students was created in Google Forms; (4) students' responses were collected and processed; (5) the research results were described and analyzed; (6) teachers' and students' responses were compared. The study involved 45 teachers and 100 foreign students, mostly from China. The majority of teachers taught at Level A2 (48\%); the majority of students studied at Level B1 (36\%). The study shows that modern teachers $(77.8 \%)$ have a high degree of adaptability, which allows them to switch to new teaching formats in two weeks. They use a variety of teaching aids: not only textbooks mandated by the curriculum (100\%), but also other textbooks $(91.1 \%)$, educational materials from the Internet $(88.9 \%)$, authentic audio/video materials (51.1\%), and self-developed educational materials (53.3\%). According to students, the most effective are the authentic materials from the Internet (45\%), and the textbook mandated by the program (41\%). Both teachers and students noted difficulties in the online training of four language skills: speaking (35.6\% of teachers and $32 \%$ of students), writing (17.8\% and $32 \%$, respectively), listening (15.6\% and $40 \%)$, and reading $(11.1 \%$ and $17 \%)$. Teachers lack personal communication with students (35.6\%), specialized online tools for teaching Russian as a foreign language (13.3\%), and effective means of monitoring the acquisition of educational material (31.1\%). They strive to solve these problems through a variety of activities, creating an atmosphere conducive to authentic communication. Research data correspond with the conclusions of methodologists about the fundamentally new nature of the relationship between teachers and students in the virtual environment, which is manifested in a less hierarchic teacher-student relationship due to greater initiative, involvement, and independence of students in an online lesson. The article presents a way to study the perception of changes in the teaching mode by teachers and students. The research enriches the e-learning knowledge area with data on how the sudden mass transition to online foreign language learning was carried out.
\end{abstract}

Keywords: foreign language, teaching methods, online learning, online teaching, COVID-19

\section{Introduction}

In the spring of 2020, due to the coronavirus pandemic, schools and universities in many countries were forced to switch to the online learning model (learning in a virtual classroom). This educational environment fundamentally differs from the customary one. We will display the contrast using the experience of teaching Russian as a Foreign Language in the Center for Additional Educational Programs at St. Petersburg State University (Russia). The following is an outline of the current situation.

First, the transition to online learning appeared to come as a surprise for teachers. Many of them were not prepared for the transition, as the issue of online learning has traditionally been on the periphery of their pedagogical reality. The teachers who found themselves most well-positioned were those who had had the experience of teaching one-on-one foreign language lessons via Skype, and had either previously used blended learning technologies or had been involved in the creation and support of Massive Open Online Courses (MOOCs). They adapted to the new conditions much faster. Most of the teachers, being full-time education professionals in the classroom environment, had no experience of teaching online. In addition, even teachers with one-on-one online learning experience had difficulty transitioning to teaching groups of foreign language students.

Second, the university executives were not ready for these changes in the educational system. Despite the promotion of distance learning systems and arranging for teachers to be trained to work in these systems, the corresponding infrastructure in higher education was not ready in many countries. This includes Russia, where there were no platforms for distance learning, no previously developed remote educational curriculum for 
academic courses, etc. As a result, in the face of the sudden transition to online learning, most teachers were unable to adapt using the new methodology. During the first few days, most teachers tried to organize lessons by email, and then almost all of them switched to online instruction over video conferencing using Skype and Zoom platforms, mastering their technological capabilities on their own.

Third, the transition to online education turned out to be unexpected for foreign students as well. They did not plan to study remotely and had come to Russia with the express intention of studying Russian, immersed in the environment of the language. These students were forced to modify their plans. For many of them, it proved to be exceedingly difficult to organize themselves and to work in the absence of ongoing teacher supervision. Many students lacked any previous experience of independent study in massive open online courses, and those who had such experience often treated it in a perfunctory manner.

Thus, in the context of the coronavirus pandemic, a new educational setting, that requires both study and reflection, has emerged. The first and the most important step in researching it should be to study those who are involved in the educational process - their psychological state, emerging problems, and possible ways to resolve them.

\section{Literature Review}

In scholarly literature, it has been repeatedly noted that online learning has an effect on the mind and activities of teachers and students, regardless of its type: blended learning courses, massive courses for independent study, one-on-one learning, virtual classroom using video conferencing, etc. This psychological and pedagogical facet of online education has proved to be one of the most important aspects of academic research in the study of online instruction in various academic subjects, including in the teaching and learning of a foreign language (Bertin, Grave, and Narcy-Combes, 2010; Burns, 2011; Moore and Kearsley, 2005; White, 2003, etc.).

Over the past 20 years, the attention of scholars from around the world has been focused on the psychological characteristics of teachers working online. Researchers have suggested different sets of skills or competencies needed by online teachers, and those, in turn, became the starting point for organizing such teacher training courses.

The first of these works was a book written by C. White (2003), in which the competencies of a distance course tutor are described. The author believes that tutors "will be expected to: adjust their practice to distance language learning environments; counsel learners in their adaptation to distance; identify the characteristics and needs of language learners at a distance; provide ongoing support for learners in new and unfamiliar learning environments; monitor individual learners and the course; respond to a new and different range of issues and affective states in relationships with learners; provide motivating support and tasks at a distance; support students at a distance and help them to become responsible for their learning; work as part of a team with technology experts, learning support staff, etc.; understand the advantages and disadvantages of new language learning environments, and develop appropriate strategies and relevant responses; operate in a context of ongoing change and innovation" (White, 2003, p. 69).

Hampel and Stickler (2005) put forth a hierarchy of new skills/competencies required for tutors in the context of online learning. The authors presented their work in the form of a skills pyramid. Its lowest level is Basic ICT competence, and the following components are built upon it: specific technical competence for the software, dealing with constraints and possibilities of the medium, online socialization, facilitating communicative competence, creativity and choice, and the teacher's own style (Hampel and Stickler, 2005, p. 317). Later, Hampel (2009), relying on this pyramid, developed a program for preparing foreign language teachers to work online.

Turkovskaya (2011) identified 47 professionally significant qualities of a distance learning teacher, including analytical thinking, energy, thoughtfulness, politeness, virtual communication skills, and others. The set of these qualities can also serve as the foundation for training online teachers.

Nikulicheva (2013) developed a profile of necessary qualifications for teachers in the field of distance learning, which included pedagogical and psychological competencies, as well as competencies in the field of information technology. In addition, she described in detail the main problems of a distance learning teacher - 
organizational, methodological, communicative, technical, as well as the problems of the teacher's selfdevelopment.

Kalinin (2015) identified the difficulties that teachers experience in the distance learning system, among which are the subjective difficulties of beginner PC users, stress that leads to a loss of control over activities, and a lack of confidence, which causes low activity and the desire to avoid situations that can damage self-esteem. He identified the following reasons for these difficulties: a low level of technical aptitude, inability to organize effective interaction with students, inability to adjust from traditional forms of education to new forms, inability to use active teaching methods, conservatism, lack of flexibility, rejection of new pedagogical technologies.

Chelnokova and Tjumaseva (2016) link the skills necessary for a tutor with the main types of the tutor's activities, that is, with creating methodological support, monitoring the digestion of educational material by students, creating an educational environment which corresponds to the conditions of learning, providing technological support, etc.

According to Zankov (2019), the main features of activity of a foreign language teacher in an online environment are flexibility, mobility and client focus, which can be achieved if the teacher combines the professions of a linguist, methodologist, psychologist, manager, marketer, and developer of educational content. The author concludes that the combination of the functions of different professions contributes to the improvement of the teacher's competence and ensures systematization, flexibility, competitiveness, and efficiency of work in an online environment.

There is a notable series of papers that present the results of empirical research related to the professional skills of an online teacher. For example, a remarkable study is described by Ernest, Heiser and Murphy (2013), employees of the Department of Languages at The Open University (UK) and the Universitat Oberta de Catalunya (Spain). For teachers of a foreign language to be aware of the peculiarities of working in a virtual environment, they were offered the opportunity to take a joint online foreign language course. The results of this project were studied using an open-closed questionnaire and interviews.

Comas-Quinn, de Los Arcos and Mardomingo (2012), having analyzed the relationship between teachers and students in a virtual environment, concluded that online learning could only be successful if students were motivated and displayed active engagement and independence. This inevitably leads to a change in the traditional hierarchy and relationship between teachers and students. The authors state that these relationships are always in a state of flux as new hierarchies and relationships are constantly being formed.

The psychological characteristics of students are also considered by Arispe and Blake (2012). The authors found that student conscientiousness provides the best results in blended learning. In addition, they determined that students with a low level of foreign language proficiency are most interested in working with online materials, as this allows them to work on the Internet at their own pace.

According to the study by West (2011), attributes of students such as independence, learning performance, interaction with other learners, and satisfaction affect the success of distance learning.

From the point of view of the organization of the educational process, online learning requires new forms, models, and styles of teaching. This is because the roles of the teacher and the student change and the educational landscape changes completely, due to sophisticated communication technologies. "Traditional teacher-centred pedagogy has proven to be outdated and a constraint to the online learner. Online teachers must adopt new approaches with learners at heart" (Sun, 2011). Researchers agree that a radical shift of pedagogy towards an individualized, small group orientated, multi-dimensional model of teaching is necessary, as well as individually oriented teaching; the importance of acquiring indispensable technical and pedagogical skills is constantly emphasized (Paepe, Zhu, and Depryck, 2018). There are also methods proposed specifically for new educational design, for example, "The flipped classroom" (Tsytovich, Boronenko, and Yakusheva, 2019, etc.), but there are very few of them.

Thus, the psychological characteristics of participants in online learning are reflected quite fully and diversely in scholarly literature, and the methods of questionnaires and interviews are often used as a means of obtaining data. However, there are no studies that investigate the situation of an abrupt massive transition of teachers 
and students to online learning. Such a study would focus on teachers who previously had not specifically engaged in online learning, were not familiar with its relevant methodological literature and, as such, experienced a number of psychological, pedagogical, and technical difficulties. It would also examine the students who did not have any online learning experience.

It is the transition to online learning that this study is focused on.

\section{Methodology}

\subsection{Objective and method}

The purpose of this work is to explore the reception of an abrupt massive transition to online learning by the participants in this process - teachers and students. The most important aspect of the study was to identify the difficulties they experienced in this new educational environment and ways in which to overcome these difficulties. The research was done through surveys.

\subsection{Context}

The study was conducted at the Center for Additional Educational Programs in the field of "Russian as a Foreign Language" at St. Petersburg State University (Russia), which provides training for foreign students at six levels of Russian language proficiency, with each group consisting of 15 students. In total, 900 students studied at the Center at the time of the transition to the distance learning model.

Teachers were advised to use various online resources in teaching; for this, classrooms were equipped with interactive boards connected to the Internet. Nevertheless, offline education remained the main form of language study for foreign students at the Center for Additional Education in Russian as a Foreign Language. A small portion of teachers were able to successfully use online resources (e.g. Malyshev and Glazunova. Succes $+A 1$ ), working on systems that can be characterized as variants of computer-assisted teaching/learning and blended teaching/learning.

In March 2020, with the $100 \%$ transition of the indicated education system to the distance format (classes from March 30th onward were conducted via the Zoom platform), all the requirements for the organization of the learning process remained: the lesson schedule (20 hours of lessons of Russian as a foreign language for each group per week), along with the duration of the lesson (90 minutes), and compliance with the approved programs (changes in curriculum due to a change in the form of study wasn't allowed), remained in effect.

\subsection{Participants}

Forty-five teachers (out of 100 teachers working in the program) and 100 students (out of 900 students) answered the questionnaire. The varying degree of activity in the survey of teachers and students is explained by the fact that students have recently begun to learn Russian (most of them speak Russian at the A2 level) and, possibly, by ethno-cultural and age characteristics of students (most of the students are graduates of Chinese schools who are going to study at university). All of the teachers were certified to teach Russian as a foreign language, some of them had certificates confirming their competence in the field of E-Learning. Teaching experience ranged from 0 to 40 years.

Foreign students taking Russian language courses at St. Petersburg State University come from all continents, but mainly from Asia. Most of these students are Chinese citizens. All of them have e-learning tools and modern computer programs, but many have only smartphones and do not have computers or laptops, which makes online learning difficult. Many students are planning to reach the B1 level, obtain a B1 level certificate, and then enroll in various Russian universities. An important aspect of these students is their motivation: the desire to take full-time Russian language training immersed in a language learning environment.

\subsection{Instruments}

An open-closed-format questionnaire was prepared for the survey of teachers, which allowed for a maximum range of answers. Despite certain difficulties associated with their processing, these answers, in general, provide the most complete picture of the teacher's reception to the massive transition to online learning. 
Table 1: Questionnaire for teachers and its features

\begin{tabular}{|c|c|c|c|}
\hline Questions & Category/keyword & Scale & Answer type \\
\hline $\begin{array}{l}\text { How quickly did you develop } \\
\text { an online learning model? }\end{array}$ & Adaptation time & $\begin{array}{l}\text { - immediately } \\
\text { - 1-2 weeks } \\
\text { - did not develop } \\
\text { - other }\end{array}$ & $\begin{array}{l}\text { Choice of one } \\
\text { answer from those } \\
\text { proposed or an } \\
\text { Open-ended } \\
\text { response }\end{array}$ \\
\hline $\begin{array}{l}\text { What materials do you use } \\
\text { during the online lesson? } \\
\text { (Please select one or more } \\
\text { answer options). }\end{array}$ & Educational tools & $\begin{array}{l}\text { - textbook, mandated by the } \\
\text { curriculum; } \\
\text { - other textbooks; } \\
\text { - educational materials from the } \\
\text { Internet; } \\
\text { - authentic audio and video materials; } \\
\text { - self-developed materials }\end{array}$ & $\begin{array}{l}\text { Choice of one, or } \\
\text { more than one } \\
\text { answer, from those } \\
\text { proposed }\end{array}$ \\
\hline $\begin{array}{l}\text { What types of assignments } \\
\text { turned out to be ineffective } \\
\text { during an online lesson and } \\
\text { did you have to give them up? }\end{array}$ & $\begin{array}{l}\text { Ineffective study } \\
\text { assignments }\end{array}$ & & $\begin{array}{l}\text { Open-ended } \\
\text { response }\end{array}$ \\
\hline $\begin{array}{l}\text { What do you lack when } \\
\text { teaching Russian in an online } \\
\text { classroom? }\end{array}$ & Lack of resources & & $\begin{array}{l}\text { Open-ended } \\
\text { response }\end{array}$ \\
\hline $\begin{array}{l}\text { How are you trying to } \\
\text { compensate for this lack? }\end{array}$ & $\begin{array}{l}\text { Compensating for } \\
\text { lack of resources }\end{array}$ & & $\begin{array}{l}\text { Open-ended } \\
\text { response }\end{array}$ \\
\hline $\begin{array}{l}\text { The level of the group which } \\
\text { you are teaching? }\end{array}$ & $\begin{array}{l}\text { Language } \\
\text { proficiency }\end{array}$ & $\begin{array}{l}\mathrm{A} 1 \\
\mathrm{~A} 2 \\
\mathrm{~B} 1 \\
\mathrm{~B} 2 \\
\mathrm{C} 1 \\
\mathrm{C} 2\end{array}$ & $\begin{array}{l}\text { Choice from the } \\
\text { proposed, several } \\
\text { answers are } \\
\text { possible }\end{array}$ \\
\hline
\end{tabular}

For the survey of students, a closed-format questionnaire was prepared, containing questions with pre-offered answers (multiple choice).

Table 2: Questionnaire for students and its features

\begin{tabular}{|l|l|l|l|}
\hline \multicolumn{1}{|c|}{ Questions } & $\begin{array}{c}\text { Category/keywo } \\
\text { rd }\end{array}$ & Answer type \\
\hline $\begin{array}{l}\text { How quickly did you get } \\
\text { used to learning remotely? }\end{array}$ & $\begin{array}{l}\text { Time of } \\
\text { adaptation }\end{array}$ & $\begin{array}{l}\text { - I have a lot of experience in online learning, so } \\
\text { I did not have any difficulties and I didn't need } \\
\text { any time to adjust. } \\
- \text { It took me 1-2 weeks } \\
- \text { I am still not used to online lessons. }\end{array}$ & $\begin{array}{l}\text { Choose one } \\
\text { answer }\end{array}$ \\
\hline $\begin{array}{l}\text { How difficult is it to } \\
\text { communicate with the } \\
\text { teacher during an online } \\
\text { lesson? }\end{array}$ & $\begin{array}{l}\text { Student-teacher } \\
\text { communication }\end{array}$ & From 1 (minimum) to 5 (maximum) & Scale \\
\hline $\begin{array}{l}\text { How difficult is it to } \\
\text { communicate with your } \\
\text { classmates during an online } \\
\text { lesson? }\end{array}$ & $\begin{array}{l}\text { Student-student } \\
\text { communication }\end{array}$ & From 1 (minimum) to 5 (maximum) & Scale \\
\hline $\begin{array}{l}\text { How difficult is it to } \\
\text { understand the teacher and } \\
\text { your classmates during an } \\
\text { online lesson? }\end{array}$ & $\begin{array}{l}\text { Reception of } \\
\text { words of other } \\
\text { participants }\end{array}$ & From 1 (minimum) to 5 (maximum) & Scale \\
\hline $\begin{array}{l}\text { How difficult is it to work in } \\
\text { pairs during an online } \\
\text { lesson? }\end{array}$ & Working in pairs & From 1 (minimum) to 5 (maximum) & Scale \\
\hline $\begin{array}{l}\text { How difficult is it to read } \\
\text { texts on the screen during } \\
\text { an online lesson? }\end{array}$ & $\begin{array}{l}\text { Text reception on } \\
\text { the screen }\end{array}$ & From 1 (minimum) to 5 (maximum) & Scale \\
\hline $\begin{array}{l}\text { How difficult is it to } \\
\text { complete writing }\end{array}$ & $\begin{array}{l}\text { Writing } \\
\text { assignments }\end{array}$ & From 1 (minimum) to 5 (maximum) & Scale \\
\hline
\end{tabular}




\begin{tabular}{|c|c|c|c|}
\hline $\begin{array}{l}\text { assignments during an } \\
\text { online lesson? }\end{array}$ & & & \\
\hline $\begin{array}{l}\text { Does the teacher's lack of } \\
\text { response to your answers } \\
\text { interfere? }\end{array}$ & Teacher response & From 1 (minimum) to 5 (maximum) & Scale \\
\hline $\begin{array}{l}\text { What helped you focus on } \\
\text { your online lesson? }\end{array}$ & $\begin{array}{l}\text { Means of } \\
\text { retaining } \\
\text { attention }\end{array}$ & $\begin{array}{l}\text { - I liked it when the teacher gave small written } \\
\text { assignments, which we immediately checked } \\
\text { - It helped me when the teacher joked around } \\
\text { - It helped me that the teacher gave a lot of } \\
\text { homework and it was easier for me to } \\
\text { understand the lesson later } \\
\text { - The teacher's presentations helped me a lot } \\
\text { - I liked that the teacher asked questions } \\
\text { throughout the lesson, this kept me from } \\
\text { getting distracted } \\
\text { - I was helped by pictures, photos, and videos } \\
\text { that the teacher used }\end{array}$ & $\begin{array}{l}\text { Choice of } \\
\text { three from the } \\
\text { proposed } \\
\text { options }\end{array}$ \\
\hline $\begin{array}{l}\text { What materials do you find } \\
\text { most effective for working } \\
\text { in an online classroom? }\end{array}$ & Effective material & $\begin{array}{l}\text { - basic textbook, as it would be in the classroom } \\
\text { - relevant materials from the Internet } \\
\text { - materials prepared by the teacher for your } \\
\text { group }\end{array}$ & $\begin{array}{l}\text { Choice of } 1 \\
\text { answer }\end{array}$ \\
\hline $\begin{array}{l}\text { To what extent do you lack } \\
\text { online materials for learning } \\
\text { Russian as a Foreign } \\
\text { Language? }\end{array}$ & $\begin{array}{l}\text { Online learning } \\
\text { products }\end{array}$ & From 1 (minimum) to 5 (maximum) & Scale \\
\hline $\begin{array}{l}\text { How severely does your } \\
\text { computer lacking the } \\
\text { technical capabilities } \\
\text { necessary for an online } \\
\text { lesson? }\end{array}$ & $\begin{array}{l}\text { Computer } \\
\text { components }\end{array}$ & From 1 (minimum) to 5 (maximum) & Scale \\
\hline $\begin{array}{l}\text { How much do you miss the } \\
\text { usual forms of learning in } \\
\text { an online lesson (board } \\
\text { work, working in pairs, } \\
\text { game tasks)? }\end{array}$ & $\begin{array}{l}\text { Forms of } \\
\text { education }\end{array}$ & From 1 (minimum) to 5 (maximum) & Scale \\
\hline $\begin{array}{l}\text { How much emotional drive } \\
\text { do you lack in the online } \\
\text { lesson? }\end{array}$ & $\begin{array}{l}\text { Emotional } \\
\text { component of } \\
\text { the lesson }\end{array}$ & From 1 (minimum) to 5 (maximum) & Scale \\
\hline $\begin{array}{l}\text { How much self-discipline do } \\
\text { you lack in an online } \\
\text { lesson? }\end{array}$ & $\begin{array}{l}\text { Discipline, } \\
\text { organization }\end{array}$ & From 1 (minimum) to 5 (maximum) & Scale \\
\hline $\begin{array}{l}\text { What level group do you } \\
\text { study in? }\end{array}$ & $\begin{array}{l}\text { Language } \\
\text { proficiency }\end{array}$ & $\begin{array}{l}\mathrm{A} 1 \\
\mathrm{~A} 2 \\
\mathrm{~B} 1 \\
\mathrm{~B} 2 \\
\mathrm{C} 1\end{array}$ & $\begin{array}{l}\text { Choice of } 1 \\
\text { answer from } \\
\text { the answers }\end{array}$ \\
\hline
\end{tabular}

Most of the questions in the questionnaire for students are designed to find out the students' opinions about the techniques and methods of working online that were used by the teachers, and therefore it is possible to compare the attitude of the teacher and students towards the same objects and tools.

\subsection{Procedure}

The order of the researchers' actions was as follows: the compilation of a questionnaire for teachers, followed by its distribution to teachers via e-mail, and the collection and processing of their responses. Then came the compilation of questionnaires for students, conducting a survey of students using Google Forms, and the processing of their answers. This was proceeded by describing and analyzing the research results, as well as comparing the answers of teachers and students. 


\subsection{Results}

3.6.1 The presentation of the results of the survey of teachers (see Appendix A)

Answering the first question "How quickly did you develop an online learning model?", $77.8 \%$ of respondents indicated that it took them 1-2 weeks to adapt to online learning, $13.3 \%$ had previously mastered online methodology, $6.7 \%$ have not yet found the optimal model, and $2.2 \%$ did not give an answer. Accordingly, for most of the teachers, though the transition to online learning was unexpected, $77.8 \%$ adapted to the new conditions within two weeks.

In response to the second question "What materials do you use during the online lesson?", $100 \%$ of teachers answered that they used the textbook mandated by the curriculum, $91.1 \%$ used other textbooks, $88.9 \%$ used study materials from the Internet, $51.1 \%$ - authentic audio and video materials, $53.3 \%$ used their own materials, which were specially designed for specific classes. Thus, teachers use a variety of teaching aids.

For the third question, "What types of assignments turned out to be ineffective during the online lesson and did you have to give them up?", $8.9 \%$ of respondents did not give up anything, but used traditional tasks while taking into account the specifics of remote work. $35.6 \%$ of respondents noted that they had difficulties with training of speaking, $15.6 \%$ - of listening, $11.1 \%$ - of reading, $18.8 \%$ - of writing, $8.9 \%$ - of vocabulary, grammar and pronunciation. $17.8 \%$ - with classroom management. $15.6 \%$ of respondents did not answer this question at all. As can be seen, teachers do not abandon traditional types of work but note the difficulties in using them when working in an online format. The main problems are associated with teaching speaking and writing, as well as with the organization of monitoring the learning results.

Answers to the fourth question "What do you lack when teaching Russian in an online classroom?" were also diverse: $35.6 \%$ noted the lack of normal, high-quality communication with students, of classroom dynamics, and of emotional connection, and $6.7 \%$ lacked communication with colleagues; $24.4 \%$ of respondents noted a lack of student discipline and motivation, $31.1 \%$ indicated the impossibility of monitoring the work of the entire study group, and $13.3 \%$ noted a lack of Internet resources for teaching Russian to foreigners (interactive tasks, developments for specific topics, and electronic textbooks); $20 \%$ noted the absence of technical skills, $17.8 \%$ noted technical problems either among themselves or students. Thus, in answering the fourth question, teachers largely repeated what they had already written down in answers to the third question: they lack fullfledged communication with students, are not satisfied with the attitude of students towards their studies, and they note the presence of technical problems and the state of online resources.

Answering question 5 "How are you trying to compensate for this?", the teachers gave the following answers: $20 \%$ use different types of oral, written, and group assignments, $15.6 \%$ - personal qualities (humour, communication outside the classroom in chats), $8.9 \%$ focus on homework, $6.6 \%$ make up for the lack of educational materials with a variety of materials from the Internet and their own materials, $4.4 \%$ believe that the success of online learning is increased by creative tasks, as well as elements of competition, $11.1 \%$ consider greater involvement of students necessary in the learning process (i.e., an increase in the number of tasks to complete both in the classroom and at home), $11.1 \%$ use a variety of visual aids, $4.4 \%$ use e-mail and WhatsApp in addition to the Zoom program. At the same time, $17.8 \%$ of respondents generally declined to answer. Thus, teachers, on the one hand, diversify the types of tasks, expand channels of communication with students, and increase the volume of tasks, including those for independent work. On the other hand, they strive to make the learning process more interesting by attracting authentic materials from the Internet, using creative tasks, as well as elements of humour.

The last question, number 6 , was about the level of the study group: $13.3 \%$ of teachers worked with A1 level groups, $46.7 \%$ with A2 level groups, $28.9 \%$ with B1 level groups, and $11.1 \%$ with B2 level groups.

3.6.2 The presentation of the results of the survey of students (see Appendix B)

Answering the first question, $44 \%$ of students indicated that it took them 1-2 weeks to get used to distance learning; $41 \%$ of students did not need any time to get used to it; $15 \%$ of students, two months after the start of classes, were still not used to online lessons. It seems that for the students, the sudden change in the form of teaching did not create the same level of difficulty as it did for the teachers. 
Evaluating on a scale from 1 to 5 how difficult it is to communicate with a teacher during an online lesson, 38\% of students chose the average indicator, $25 \%$ did not experience any difficulties, $22 \%$ experienced minor difficulties, $8 \%$ believed that there were difficulties, and $7 \%$ believed that there were great difficulties. Apparently, for students, online communication is a more familiar form of communication than for teachers.

This idea is also confirmed by answers to the third question, which was in regards to communication with other students in the group: $31 \%$ do not see any difficulties, $21 \%$ note minor difficulties, $19 \%$ sometimes have problems, $19 \%$ agree that there are difficulties, $10 \%$ indicate significant difficulties.

The fourth question was about understanding the words of the teacher and of the other students during the online lesson: $40 \%$ chose the middle position of the scale, $22 \%$ - the minimum, $20 \%$, apparently, sometimes had problems in this area, $12 \%$ believed that it was difficult to understand others, $6 \%$ answered that it was very difficult to understand others during an online lesson. In the authors' opinion, similar answers would also have been received after an offline lesson, since the level of understanding of what was heard would likely be influenced by the degree of concentration of the student and his or her level of language proficiency, rather than the form of the lesson.

The following scale shows how students think about the opportunity to work in pairs during an online lesson: $32 \%$ chose the average answer, $26 \%$ did not notice difficulties, $20 \%$ believed that there were a few of them, $13 \%$ agreed that there were difficulties, and $9 \%$ believed that there were significant difficulties. Evidently, organizing working in pairs in online learning is generally not difficult for students.

A predictably small number of students find it difficult to read texts on the screen (4\% - very difficult and $13 \%$ difficult); $35 \%$ have no difficulty, $26 \%$ have no difficulty in general, and $22 \%$ have almost no difficulty. Most students are more accustomed to working with a screen than working with paper materials.

Completion of written assignments during an online lesson also does not cause difficulties for the majority of students: $32 \%$ of participants chose the middle position of the scale, $26 \%$ answered "unlikely", $24 \%$ - "no", and only $18 \%$ have difficulties in completing them (11\% - great difficulties, $7 \%$-difficulties).

Less predictable was the answer to the question of whether students are disturbed by the fact that they do not always see the teacher's reaction to their verbal activity. Oddly enough, this bothers only a small percentage of students ( $26 \%$ chose the minimum position, $25 \%$ - "2", $32 \%-$ " 3 ", $12 \%$ - "4" and $5 \%$ - "5").

Question 9 implied the ability to choose 3 answer options, and therefore the sum of the answers is more than $100 \%$. Thus, $63 \%$ of students were helped by pictures, photos, and videos that the teacher used; $48 \%$ chose "I liked it when the teacher gave small written assignments in the lesson, which we immediately checked", 48\% chose "it helped that the teacher gave a lot of homework and it was easier for me to understand the lesson later" and $48 \%$ chose "I liked that the teacher during the lesson asked a lot of questions, it did not allow me to get distracted"; $40 \%$ chose the option "it helped when the teacher joked", $29 \%$ - "the teacher's presentation helped". Obviously, the traditional methods of attracting and holding attention during the lesson (visual presentation of the material) remained the most beneficial for students.

Answering question 10, $41 \%$ of respondents indicated that the most effective material for an online lesson remained, as it would be in a classroom setting, a basic textbook. For $45 \%$, the most effective materials were relevant materials from the Internet, for $14 \%$ - materials that the teacher prepared for the group.

Answering question 11, regarding the lack of online products for teaching Russian as a Foreign Language, $37 \%$ chose the middle position, $27 \%$ had no problems, $22 \%$ had almost no problems, $6 \%$ admitted the existence of a problem, and only $8 \%$ of students believed that this was a serious problem.

Teachers and university heads worry about the problem of students' technical capabilities, but the students themselves in the survey are more likely to be satisfied with the capabilities of their computers: $28 \%$ have no problems, $29 \%$ have almost no problems, $29 \%$ sometimes have problems, $5 \%$ have problems, $9 \%$ have significant problems. 
Students generally do not strongly miss the usual forms of learning: on a scale from a minimum of 1 to a maximum of 5, the answers are arranged as follows: $19-24-39-8-10$.

Moreover, factors that the teachers worried about, such as the lack of personal communication or the absence of the opportunity to receive emotional stimulation, did not seem to worry the students. The results, on a scale from 1 to 5 , were as follows: $18-30-27-17-8$.

While answering question 15 "How much do you lack self-discipline in online lessons?", $36 \%$ respondents chose "there are some problems", 21\% - "almost no problems", 20\% - "no problems", 12\% - "yes, there is a problem", $11 \%$ - "a big problem".

Among the responding students, $36 \%$ studied in the $B 1$ level group, $23 \%-B 2,19 \%-A 2,19 \%-A 1,3 \%-C 1$.

\section{Data analysis and discussion}

The comparison of the results from the survey of the teachers and that of the students, with commentary.

Table 3: Category "adaptation time"

\begin{tabular}{|c|c|}
\hline Teachers & Students \\
\hline $\begin{array}{l}\text { How quickly did you develop a model for conducting an } \\
\text { online lesson? } \\
\begin{array}{l}\text { - } \\
\text { - } \\
\text { - } \\
\text { lesson }\end{array} \\
\text { - } 6.8 \% \text { - had the skills for conducting an online } \\
\text { - } 2.2 \% \text { - no answer }\end{array}$ & $\begin{array}{l}\text { How quickly did you get used to learning remotely? } \\
\text { - } 1-2 \text { weeks }-44 \% \\
\text { - I already had experience }-41 \% \\
\text { - I am not used to it }-15 \%\end{array}$ \\
\hline
\end{tabular}

Table 3 shows that, despite the abruptness of the introduction to distance learning, along with the general psychological and methodological unpreparedness for this format of teaching, only $13.3 \%$ of teachers note that they have long mastered the methodology of conducting an online lesson, while $77.8 \%$ of teachers were able to adapt to this new form in 1-2 weeks and developed an optimal model for an online lesson. This was facilitated by the fact that $41 \%$ of the students had prior distance learning experience. Only $15 \%$ of students note that they are not used to the distance format; $6.7 \%$ of teachers believe that they have not yet found the optimal model. This means that modern teachers have a high degree of adaptability, which allows them to quickly adapt to new teaching challenges.

Table 4: Category "teaching aids"

\begin{tabular}{|l|l|}
\hline Teachers & Students \\
\hline What materials do you use during the online lesson? & What materials do you find most effective for working \\
- textbook mandated by the curriculum - 100\%; & in an online classroom? \\
- other textbooks - $91 \%$; & - Materials prepared for the group by the teacher $-14 \%$ \\
- educational materials from the Internet $-88.9 \%$, & - Basic textbook, as it would be in the classroom - $41 \%$ \\
- authentic audio and video materials - 51.1\%; & - Authentic/relevant materials from the Internet - $45 \%$ \\
- self-developed materials - 53.3\%. & \\
\hline
\end{tabular}

Table 4 shows that $100 \%$ of teachers use the textbooks mandated by the curriculum in teaching, which is largely explained by the requirement to work according to the approved programs and use the mandated textbooks. However, in the context of online learning, reliance on these textbooks is not enough, so teachers use other materials available to them. Only $53.3 \%$ of teachers develop their own materials specifically for their study group, which, can be explained, either by their inability to create such materials, or by the lack of time to develop them. It should be borne in mind that from the point of view of $14 \%$ of students, these materials are most effective for working in an online classroom. At the same time, the results of the survey showed that students also preferred to work with a basic textbook (41\%) and with up-to-date materials from the Internet (45\%).

The requirement by the university to work in the online learning environment, according to the approved programs, and to use the mandated textbooks, can be considered a factor that restrains the initiative of teachers and their desire to experiment, which are necessary in the search for new teaching methods and techniques. Teachers working in a new educational environment need to be given more freedom in choosing the content, methods, and means of teaching. 
Table 5: Category "ineffective learning assignments"

\begin{tabular}{|c|c|}
\hline Teachers & Students \\
\hline $\begin{array}{l}\text { What types of assignments appeared to be } \\
\text { ineffective during the online lesson and did } \\
\text { you have to give them up? }\end{array}$ & $\begin{array}{l}\text { How difficult is it to communicate with a teacher during an online lesson? } \\
38 \% \text { (there are some problems); } 25 \% \text { (not difficult); } 22 \% \text { (not very } \\
\text { difficult); } 8 \% \text { (difficult); } 7 \% \text { (very difficult) }\end{array}$ \\
\hline $\begin{array}{l}35.6 \% \text { - difficulties in the online training of } \\
\text { speaking }\end{array}$ & $\begin{array}{l}\text { How difficult is it to communicate with your groupmates during an online } \\
\text { lesson? } \\
31 \% \text { - not difficult, } 21 \% \text { - not very difficult, } 19 \% \text { - there are some } \\
\text { problems, } 19 \% \text { - difficult, } 10 \% \text { - very difficult } \\
\text { How difficult is it to work in pairs during an online lesson? } \\
32 \% \text { - there are some problems, } 26 \% \text { - not difficult, } 20 \% \text {-almost not } \\
\text { difficult, } 13 \% \text { - difficult, } 9 \% \text { - very difficult }\end{array}$ \\
\hline $17.8 \%$ - difficult to control & $\begin{array}{l}\text { Does the teacher's lack of response to your answers interfere? } \\
32 \% \text { - there are some problems, } 26 \% \text { - does not interfere, } 25 \% \text { - hardly } \\
\text { interferes, } 12 \% \text { - interferes, } 5 \% \text { - interferes very much }\end{array}$ \\
\hline $\begin{array}{l}17.8 \% \text { - difficulties in the online training of } \\
\text { writing }\end{array}$ & $\begin{array}{l}\text { How difficult is it to complete writing assignments during an online } \\
\text { lesson? } \\
32 \% \text { - there are some problems, } 26 \% \text { - not very difficult, } 24 \% \text { - not } \\
\text { difficult, } 11 \% \text { - very difficult, } 7 \% \text { - difficult }\end{array}$ \\
\hline $\begin{array}{l}15.6 \% \text { - difficulties in the online training of } \\
\text { listening }\end{array}$ & $\begin{array}{l}\text { How difficult is it during the online lesson to understand the words of the } \\
\text { teacher and groupmates? } \\
40 \% \text { - there are some problems, } 22 \% \text { - not difficult, } 20 \% \text { - not very } \\
\text { difficult, } 12 \% \text { - difficult, } 6 \% \text { - very difficult }\end{array}$ \\
\hline $\begin{array}{l}11.1 \% \text { - difficulties in the online training of } \\
\text { reading }\end{array}$ & $\begin{array}{l}\text { How difficult is it to read texts on the screen during an online lesson? } \\
35 \% \text { - not difficult, } 26 \% \text { - there are some problems, } 22 \% \text { - not very } \\
\text { difficult, } 13 \% \text { - difficult, } 4 \% \text { - very difficult }\end{array}$ \\
\hline
\end{tabular}

The data in Table 5 show that both teachers and students note difficulties in the online training of speaking (35.6\% of teachers and $32 \%$ of students), writing ( $17.8 \%$ and $32 \%$, respectively), listening ( $15.6 \%$ and $40 \%)$, and reading ( $11.1 \%$ and $17 \%)$. These difficulties are objective. Language skills development requires not only the orientation of students in learned speech actions, but their intensive training in authentic situations. Even in traditional teaching, this training has a bit of an artificial character. In online learning, the level of its artificiality increases exponentially.

Table 6: Category "lack of resources"

\begin{tabular}{|c|c|}
\hline Teachers & Students \\
\hline Online products $-13.3 \%$ & $\begin{array}{l}\text { Is there a lack of online materials for learning Russian as a Foreign } \\
\text { Language? } \\
37 \% \text { - there are some problems, } 27 \% \text { - no problems, } 22 \% \text { - almost no } \\
\text { problems, } 8 \% \text { - a big problem, } 6 \% \text {-yes, there is a problem }\end{array}$ \\
\hline $\begin{array}{l}\text { Lack of communication (real full-fledged } \\
\text { face-to-face communication with students) } \\
-35.6 \% \\
\text { Communication with colleagues }-6.7 \%\end{array}$ & $\begin{array}{l}\text { Do you lack emotional drive in online lessons? } \\
30 \% \text { - almost no problems, } 27 \% \text { - there are some problems, } 18 \% \text { - no } \\
\text { problems, } 17 \% \text { - yes, there is a problem, } 8 \% \text { - a big problem }\end{array}$ \\
\hline $\begin{array}{l}\text { Lack of physical items (board, classroom } \\
\text { space, library, books) }-6.7 \%\end{array}$ & $\begin{array}{l}\text { How much do you lack the usual forms of learning in an online lesson } \\
\text { (board work, working in pairs, game tasks)? } \\
39 \% \text { - there are some problems, } 24 \% \text { - almost no problems, } 19 \% \text { - no } \\
\text { problems, } 10 \% \text { - a big problem, } 8 \% \text { - yes, there is a problem }\end{array}$ \\
\hline $\begin{array}{l}\text { Lack of control over students }-31.1 \% \\
\text { Lack of discipline and motivation of } \\
\text { students }-24.4 \%\end{array}$ & $\begin{array}{l}\text { How much do you lack self-discipline in online lessons? } \\
36 \% \text { - there are some problems, } 21 \% \text { - almost no problems, } 20 \% \text { - no } \\
\text { problems, } 12 \% \text { - yes, there is a problem, } 11 \% \text { - a big problem }\end{array}$ \\
\hline $\begin{array}{l}\text { Technical problems }-17.8 \% \\
\text { Lack of technical skills }-20 \%\end{array}$ & $\begin{array}{l}\text { To what extent does your computer lack the technical capabilities for an } \\
\text { online lesson? } \\
29 \% \text { - almost no problem, } 29 \% \text { - there are some problems, } 28 \% \text { - no } \\
\text { problem, } 9 \% \text { - a big problem, } 5 \% \text { - yes, there is a problem }\end{array}$ \\
\hline
\end{tabular}

Table 6 shows that teachers lack personal communication with students (35.6\%), and the result of this lack may be both psychological discomfort and an inability to organize lessons appropriately. Other positions, which the teachers took in their answers, were also predictable: special online materials that make the teacher's work 
more manageable (13.3\% would like to see more of them), physical objects are the usual material for explanation in the classroom (6.7\% say they are irreplaceable), organizing control in an online class is a unique endeavour (31.1\% understand that they do not yet have the skills to perform it).

The answers of the students show that they generally agree with the indicated problems, but do not find them particularly serious (to all questions of this group, the majority of answers are close to the middle ("there are some problems").

Table 7: Category "compensating for lack of resources"

\begin{tabular}{|l|l|}
\hline Teachers & Students \\
\hline How are you trying to compensate for this lack? & What helps you focus on your online lesson? \\
\hline $\begin{array}{l}\text { Creativity, humour, communication outside the classroom } \\
\text { in chats }-15.6 \%\end{array}$ & The teacher's jokes $-40 \%$ \\
\hline Different types of oral, written, group assignments - 20\% & $\begin{array}{l}\text { Small written assignments that were immediately } \\
\text { checked - 48\% }\end{array}$ \\
\hline Asked more questions $-11.1 \%$ & Questions during the lesson $-48 \%$ \\
\hline Focus on homework $-8.9 \%$ & A lot of homework $-48 \%$ \\
\hline Visuals $-11.1 \%$ & Pictures, photos, videos.... $-63 \%$ \\
\hline Additional technical means $-4.4 \%$ & \\
\hline Additionally prepared materials $-11.1 \%$ & The teacher's presentations $-29 \%$ \\
\hline
\end{tabular}

Table 7 shows that not all teachers found a way to compensate for the lack of resources, which in answer to another question, they had considered a problem. However, most often, teachers try to diversify the types of teaching assignments (20\%) and use humour and jokes (15.6\%). Students, on the other hand, quite unanimously believe that the use of pictures, photographs and other visual materials is the most effective (63\%), and not all the students are motivated to work actively in the lesson by the teacher's jokes (40\%).

\section{Conclusions}

As a result of the survey of teachers and students, the peculiarities of their perceptions of the new educational environment, along with ways of adapting to this environment, were identified. The analysis of the research results allowed for the following conclusions to be made.

1. The adaptation of the majority of teachers and students to the new educational environment took 1-2 weeks. Modern teachers of a foreign language have a high degree of adaptability, which allowed them to adapt to a new teaching format in a short amount of time.

2. All teachers, in the context of an emergency transition to online education, work according to the textbook, which is mandated by the curriculum and was used in traditional classroom teaching. At the same time, almost all teachers are aware of its insufficiencies and use other teaching materials. With that said, about half of the teachers do not use their own materials for online instruction, which might be due to either their inability to create them, or to the lack of time to prepare for classes in this new environment. It is absolutely necessary to train teachers on how to create these materials, since, according to the results of a questionnaire of students, educational materials specially developed for online lessons are the most engaging.

3. The desire of teachers to preserve the features of traditional education in an online setting can be largely explained by the requirement to work according to approved programs and to use mandated textbooks. However, this can be viewed as a factor that holds back their initiative and desire to experiment. Teachers working in an online learning environment need to be given more freedom in the choice of content, methods, and means of teaching.

4. Teachers are aware of the ineffectiveness of many traditional teaching methods, as well as the impossibility of classroom management in online learning. The main difficulties they highlight are the lack of full-fledged communication with students and a loss of control. The limited interaction with other students and the teacher is also noted by students as a disadvantage of online learning.

5. All teachers have difficulties in training of four language skills, in teaching vocabulary, grammar and pronunciation, as well as classroom management. They try to solve emerging problems through a variety of tasks and by creating an atmosphere conducive to communication. This correlates with the conclusions of methodologists about a fundamentally new nature in the relationship between teachers and students in a virtual environment, which is manifested by the change in the hierarchy of "teacher- 
student" relations due to greater initiative, involvement, and independence of students in online learning.

\section{References}

Arispe, K. and Blake, R.J., 2012. Individual factors and successful learning in a hybrid course. System: An International Journal of Educational Technology and Applied Linguistics, 40(4), pp. 449-465.

Bertin, J.-C., Grave, P. and Narcy-Combes, J.-P., 2010. Second language distance learning and teaching: Theoretical perspectives and didactic ergonomics. Hershey, PA: Information Science Reference.

Blake, R. J., 2013. Brave new digital classroom: Technology and foreign language learning. Washington, DC: Georgetown University Press.

Burns, M., 2011. Distance education for teacher training: modes, models, and methods. Washington, DC: Education development center, Inc.

Chelnokova, E.A. and Tjumaseva, Z.I., 2016. Tutor activities in distance learning. Vestnik of Minin university, 3(16), pp. 1734.

Comas-Quinn, A., de los Arcos, B. and Mardomingo, R., 2012. Virtual learning environments (VLEs) for distance language learning: Shifting tutor roles in a contested space for interaction. Computer Assisted Language Learning, 25 (2), pp. 129-143.

Ernest, P., Heiser, S. and Murphy, L., 2013. Developing teacher skills to support collaborative online language learning. Language Learning Journal, 41 (1), pp. 37-54.

Hampel, R., 2009. Training teachers for the multimedia age: Developing teacher expertise to enhance online learner interaction and collaboration. Innovation in Language Learning and Teaching, 3 (1), 35-50.

Hampel, R. and Stickler, U., 2005. New skills for new classrooms: Training tutors to teach languages online. Computer Assisted Language Learning, 18 (4), pp. 311-326.

Kalinin, D.A., 2015. Difficulties, experienced by teachers in distance learning. [online] Naukovedenie, 7 (3). DOI: 10.15862/30PVN315

Malyshev G.G. and Glazunova O.I. Succes+A1. [online] Russian language and culture institute (SPbU). Available at: $<$ http://elementaryrussian.spbu.ru/ > [Accessed 25 July 2020].

Moore, M.G. and Kearsley, G., 2005. Distance education: A systems view of online learning, Second edition. Belmont, CA: Wadsworth.

Nikulicheva, N.V., 2013. Qualification data as a basis for teacher training distance learning. Otkrytoe obrazovanie (Open Education), 5(100), pp. 16-23.

Paepe, L., Zhu, Ch., and Depryck, K., 2018. Online language teaching: Teacher perceptions of effective communication tools, required skills and challenges of online teaching. Journal of Interactive Learning Research, 29(1), pp.129-142.

Sun, S.Y.H., 2011. Online language teaching: the pedagogical challenges. Knowledge Management and E-Learning, 3(3), pp.428-447.

Tsytovich, M.V., Boronenko, G.F., and Yakusheva, O.V., 2019. Flipped classroom technology and its implementation at various levels of higher education. Bulletin of the South Ural State University. Ser. Education. Educational Sciences, 11 (3), pp. 21-32. Doi: 10.14529/ped190302.

Turkovskaya, N.V., 2011. Professionally important qualities of a distance learning lecturer. Bulletin of the South Ural State Humanitarian Pedagogical University, 10, pp. 159-177.

Volle, L. 2005. Analyzing oral skills in voice e-mail and online interviews. Language Learning and Technology Journal, 9 (3), pp.146-164.

West, E.R., 2011. Insights from research on distance education learners, learning, and learner support. American Journal of Distance Education, 25 (3), pp. 135-148.

White, C., 2014. The distance learning of foreign languages: A research agenda. Language Teaching, 47 (4), pp. 538-553.

White, C., 2003. Language learning in distance education. Cambridge, UK: CUP.

Zankova, A.A., 2019. Teacher of russian as a foreign language in the system of non-formal education in the online environment. Prepodavatel 21 vek (Teacher. 21 century), 1, pp. 177-186. 


\section{Appendices}

Appendix A: Results of the survey of teachers.

Question 1: How quickly did you develop an online learning model?

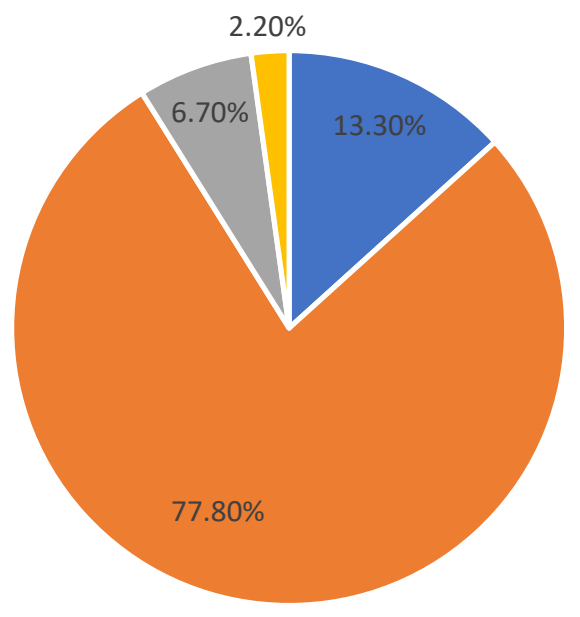

- I had previously mastered online methodology.

- It took me 1-2 weeks to adapt to online learning.

- I have not yet found the optimal model.

- No answer.

Question 2: What materials do you use during the online lesson?

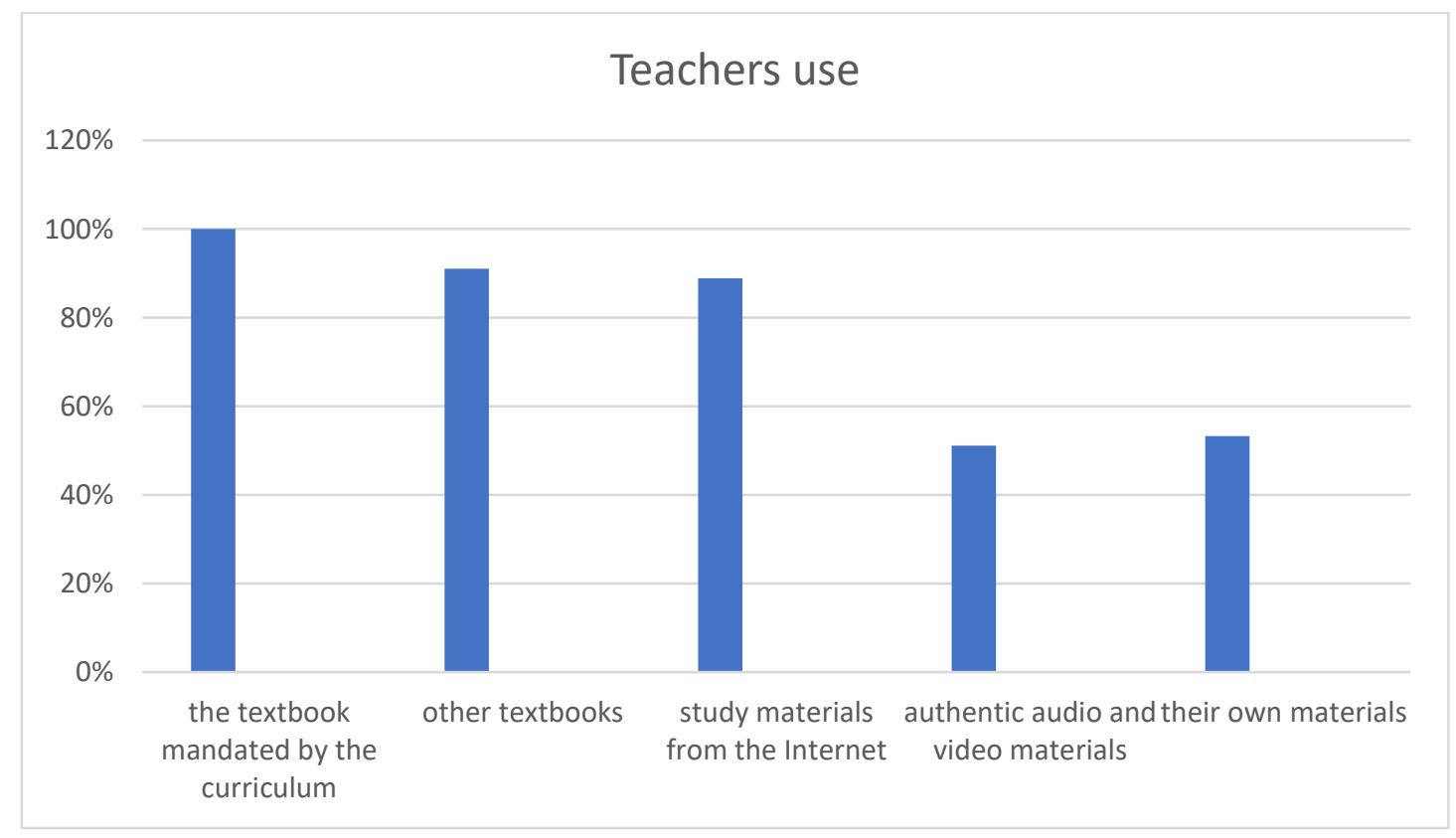


Question 3: What types of assignment turned out to be ineffective during the online lesson and you had to give up?

\section{Teachers (\%)}

40

35.6

35

30

25

20

15

10

8.9

5

0

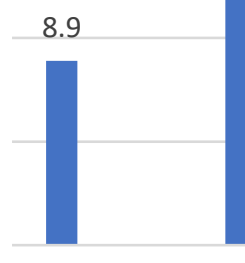

did not give up anything

had had difficulties difficulties of speaking of listening
18.8

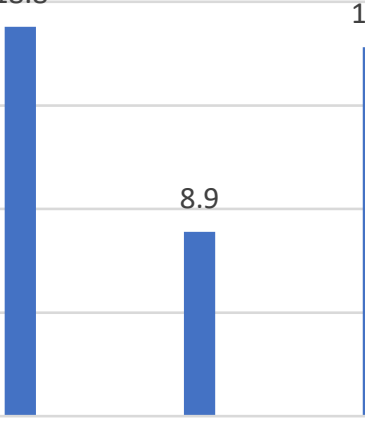

had

had difficulties difficulties with teaching of writing
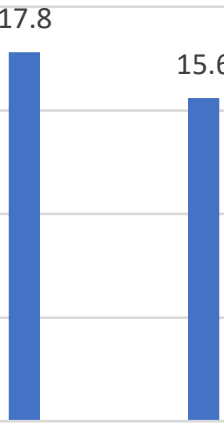

had difficulties with classroom grammar and management pronunciation 
Question 4:What do you lack when teaching Russian in an online classroom?

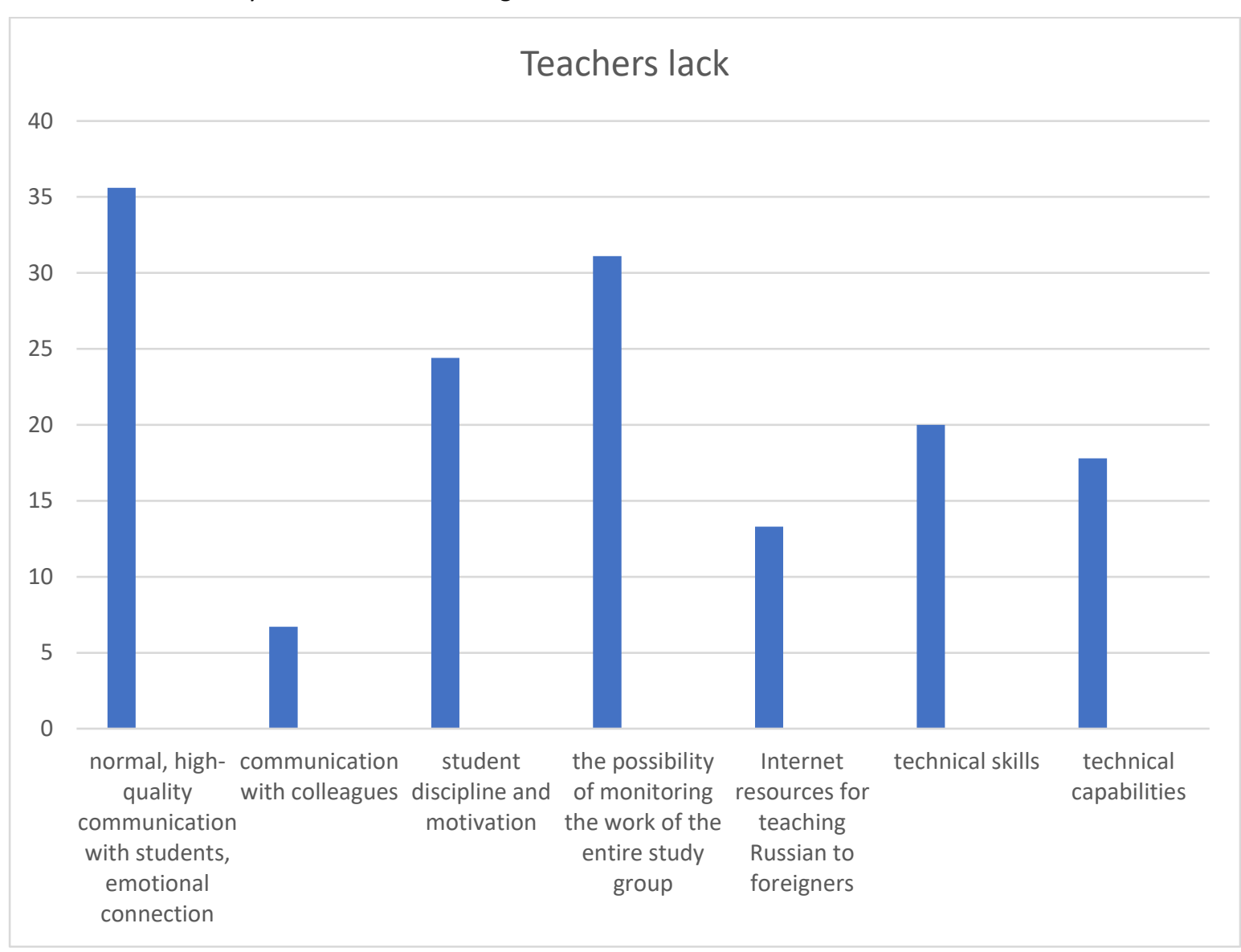

Question 5: How are you trying to compensate for this?

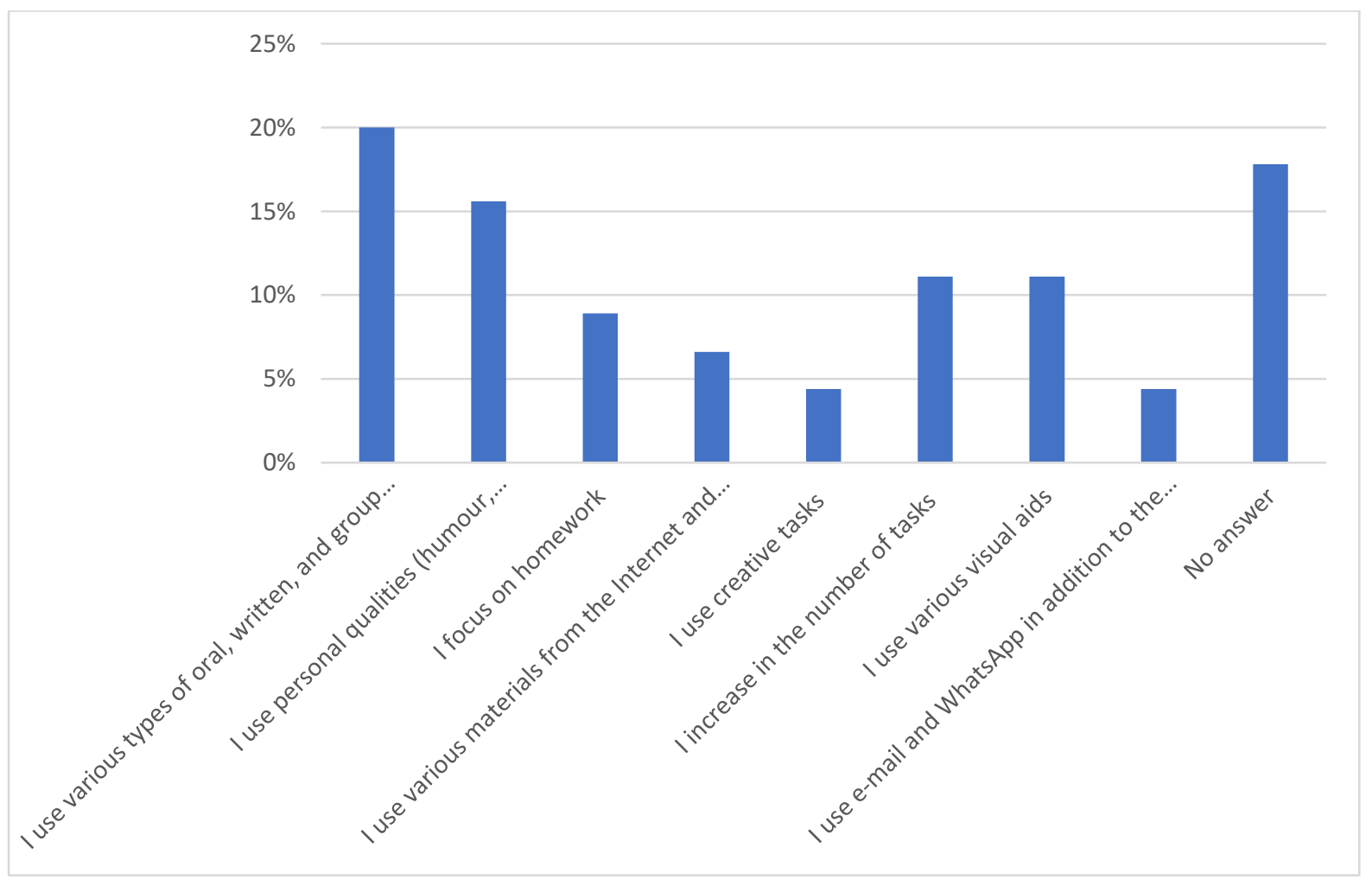


Question 6: The level of the group you are teaching.

\section{Level of language proficiency}

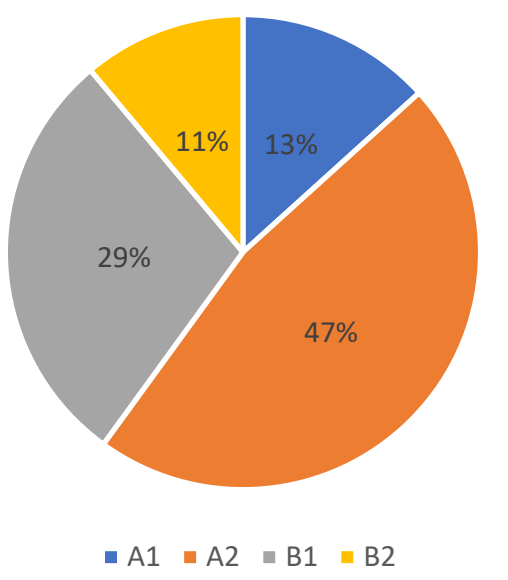

Appendix B: Results of the survey of students

https://docs.google.com/forms/d/1ZfsJKd5EKuxLR9g7RguJ01IwNJsaJpNLk09o5M-oGDE/edit\#responses

Question 1: How quickly did you get used to learning remotely?

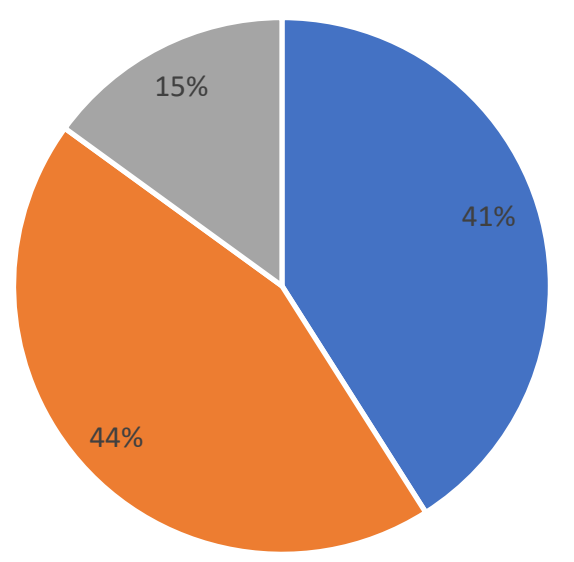

- I have a lot of experience in online learning $=$ It took me 1-2 weeks

- I am still not used to online lessons 
Question 2: How difficult is it to communicate with the teacher during an online lesson?

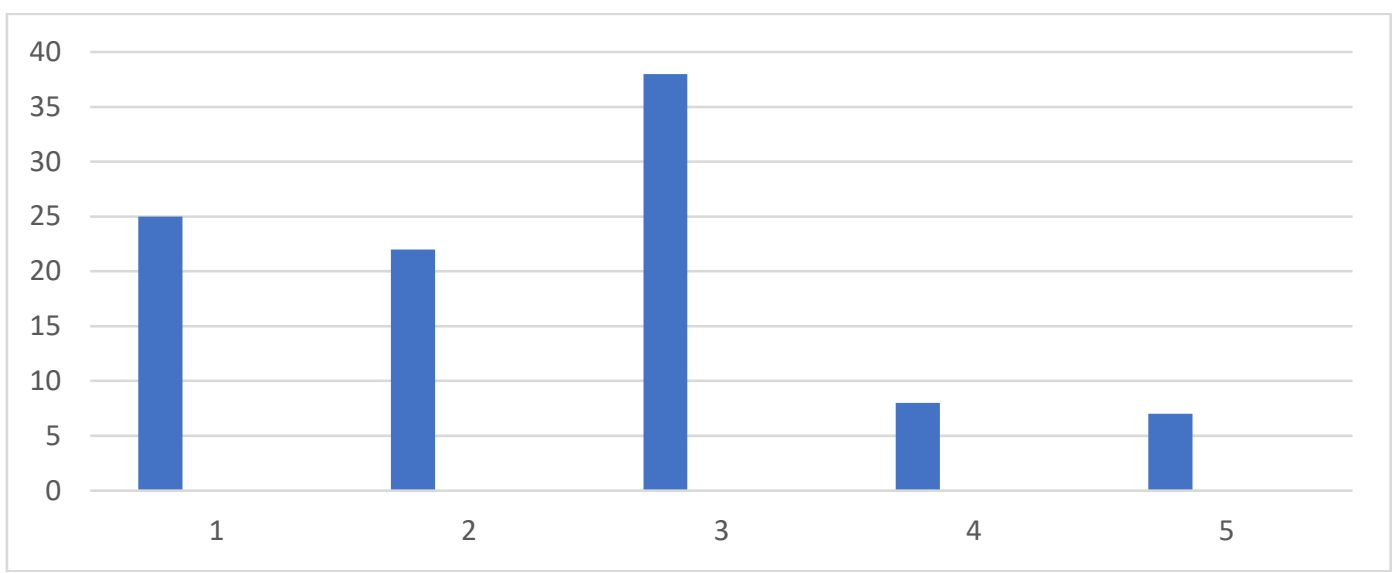

Question 3: How difficult is it to communicate with your classmates during an online lesson?

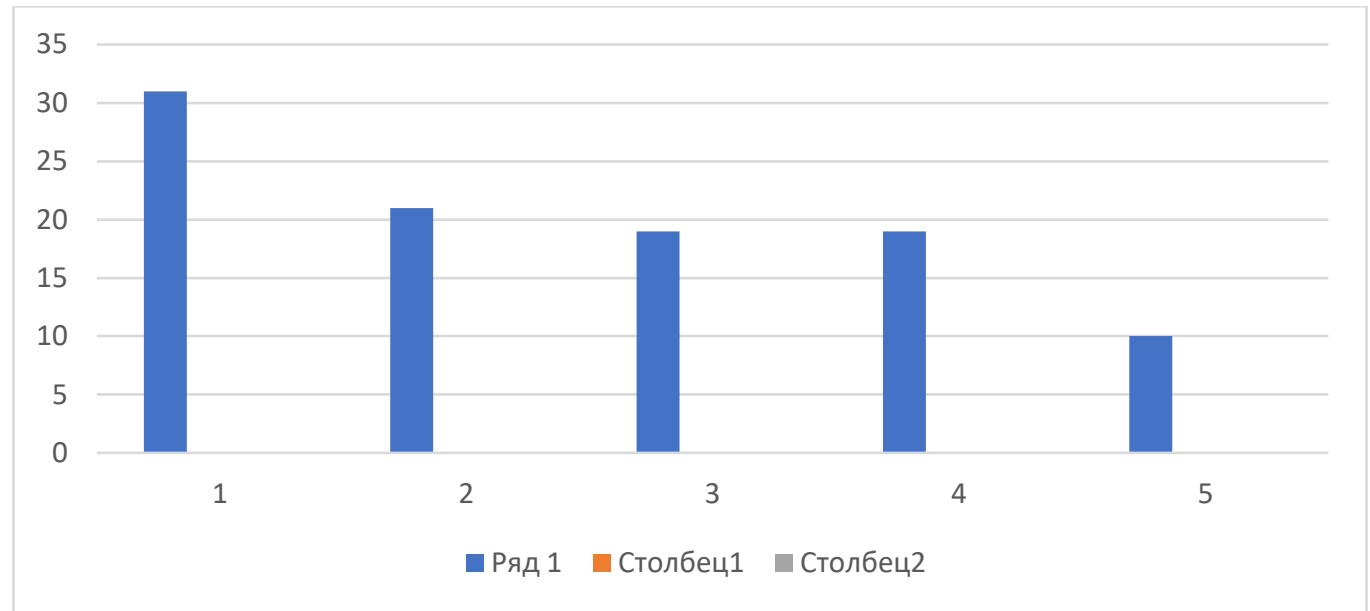

Question 4: How difficult is it to understand the teacher and your classmates during an online lesson?

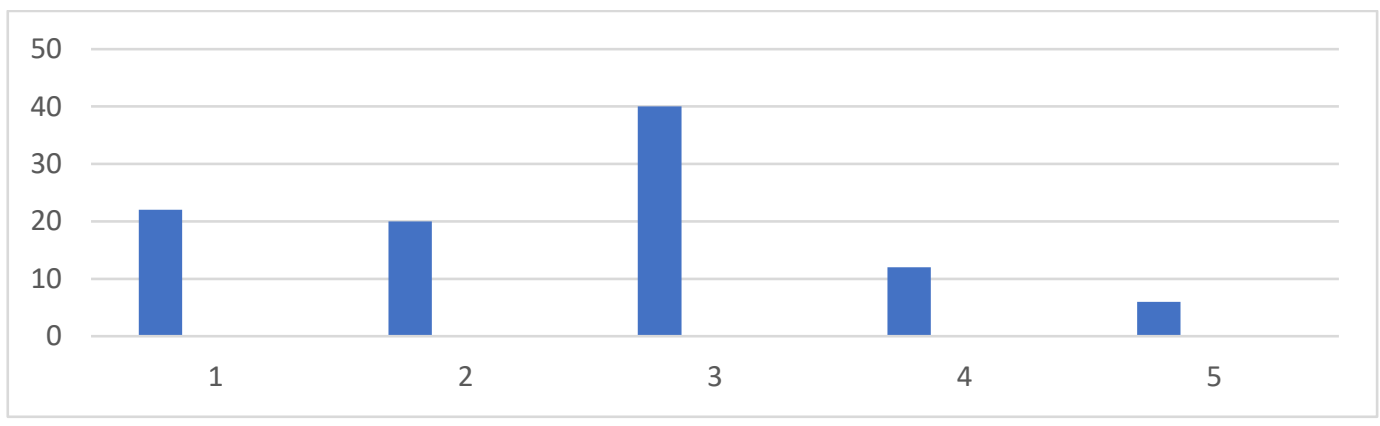

Question 5: How difficult is it to work in pairs during an online lesson?

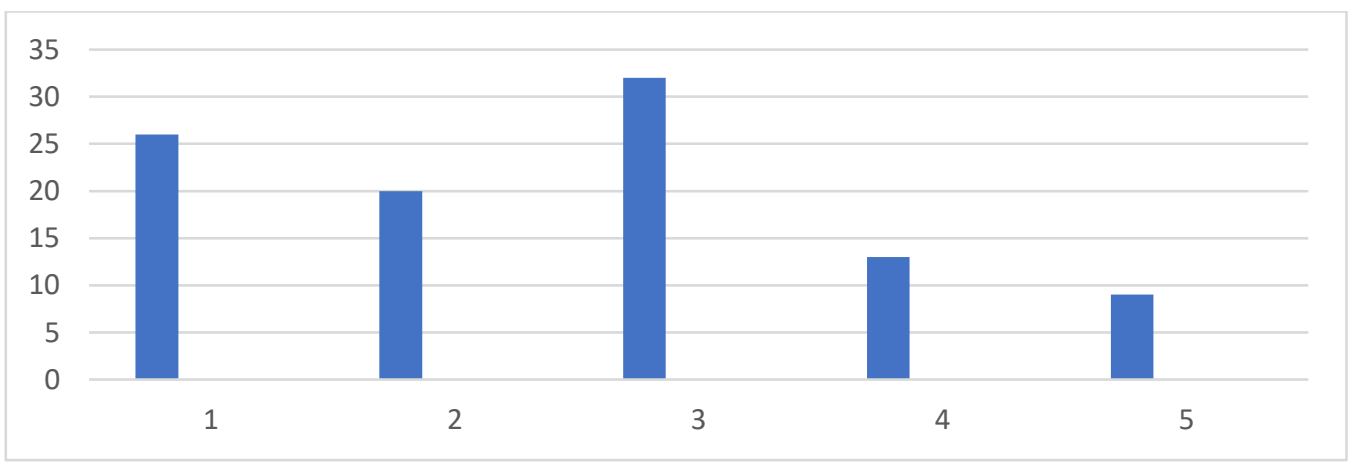


Question 6: How difficult is it to read texts on the screen during an online lesson?

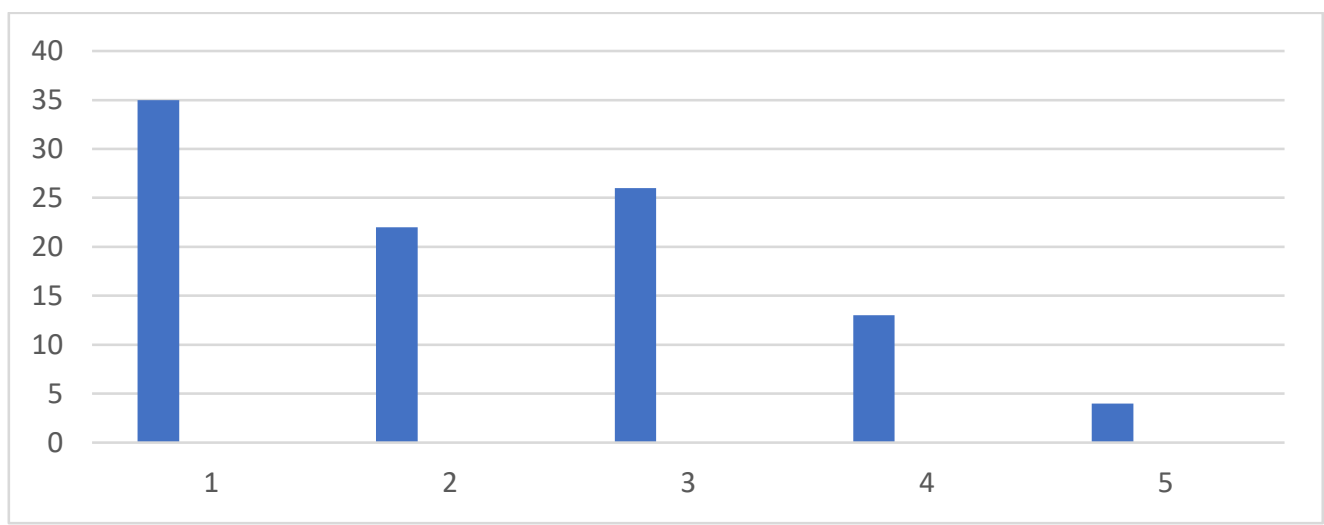

Question 7: How difficult is it to complete writing assignments during an online lesson?

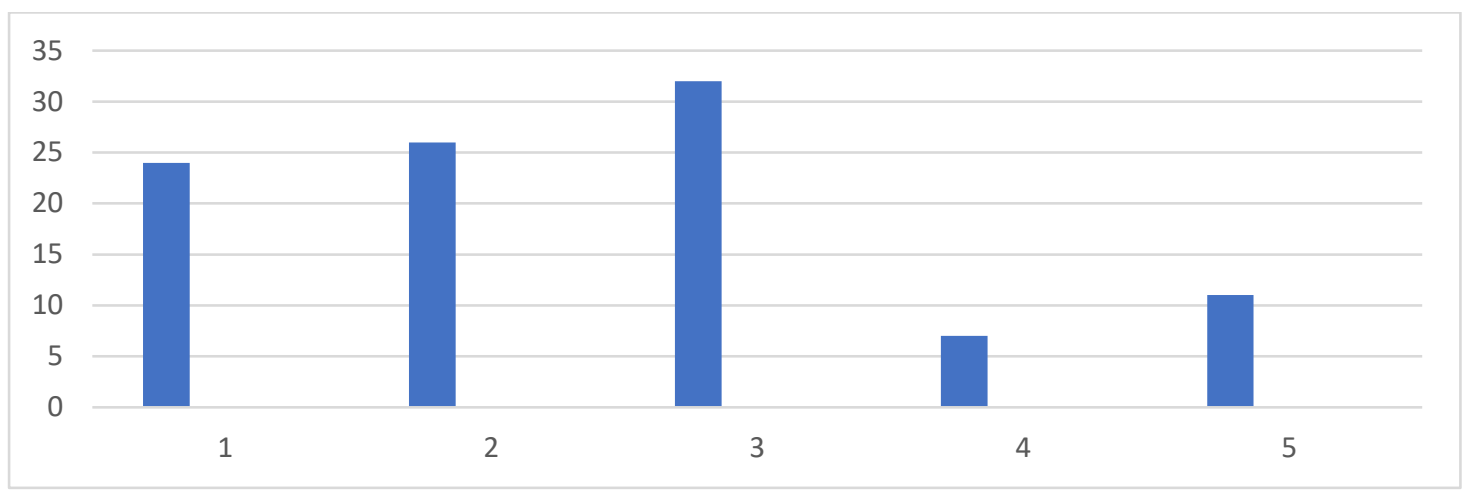

Question 8: Does the lack of teacher's response to your answers interfere?

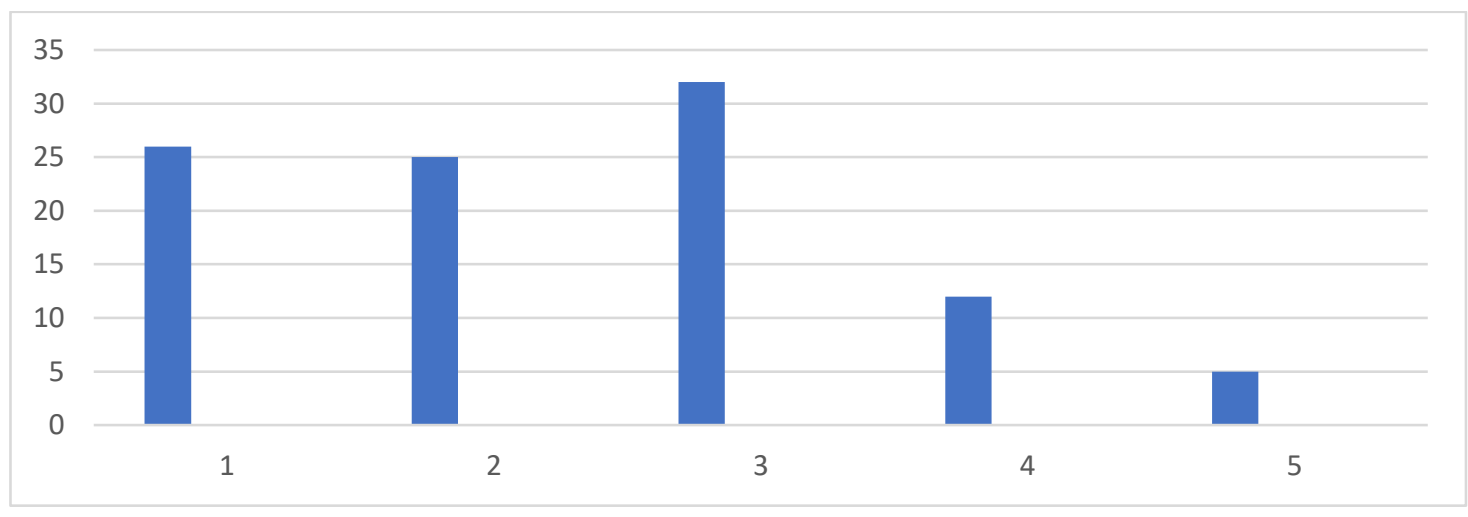


Question 9: What helped you focus on your online lesson? (Pick 3 most important options)

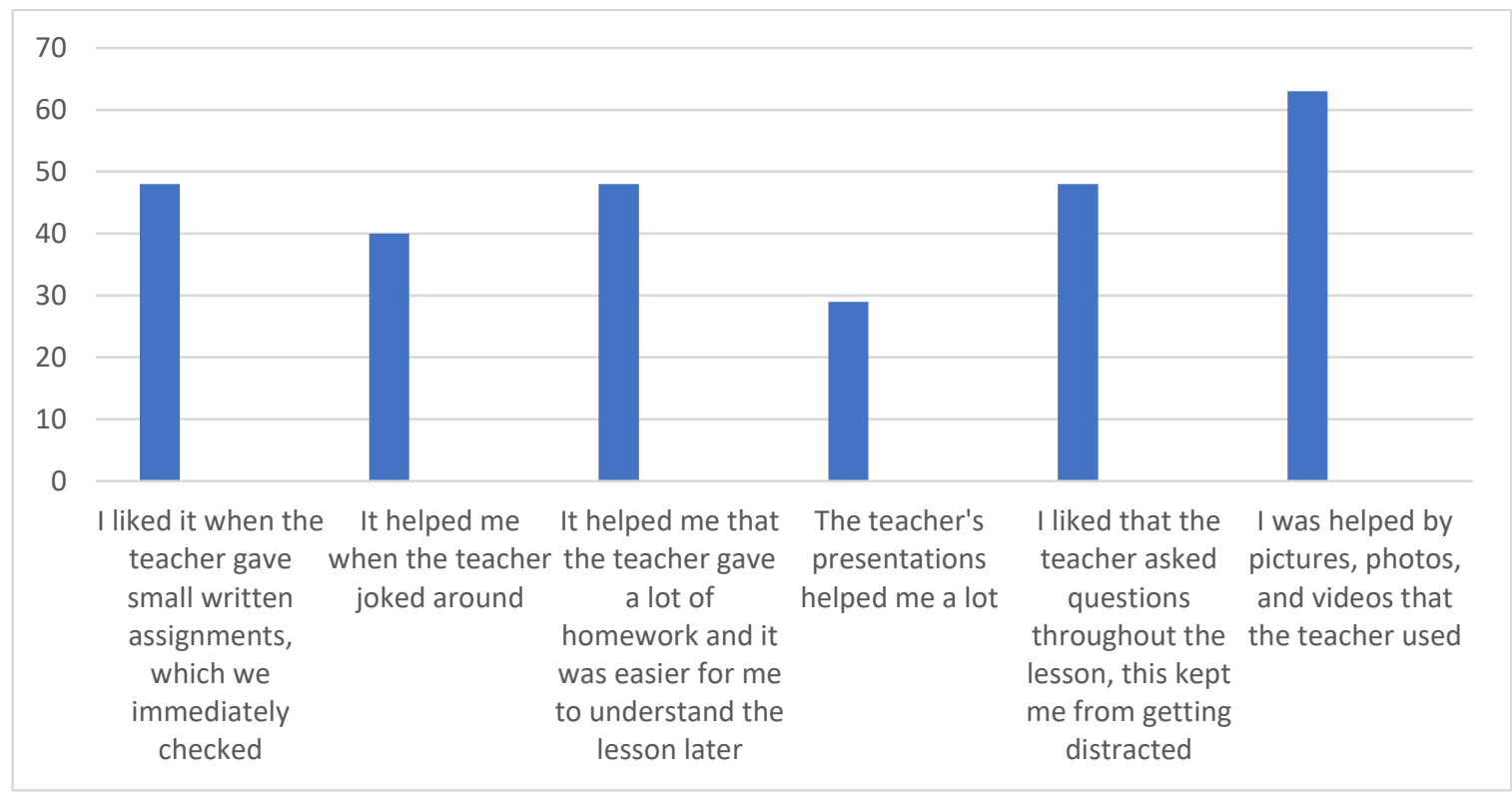

Question 10: What materials do you find most effective for working in an online classroom?

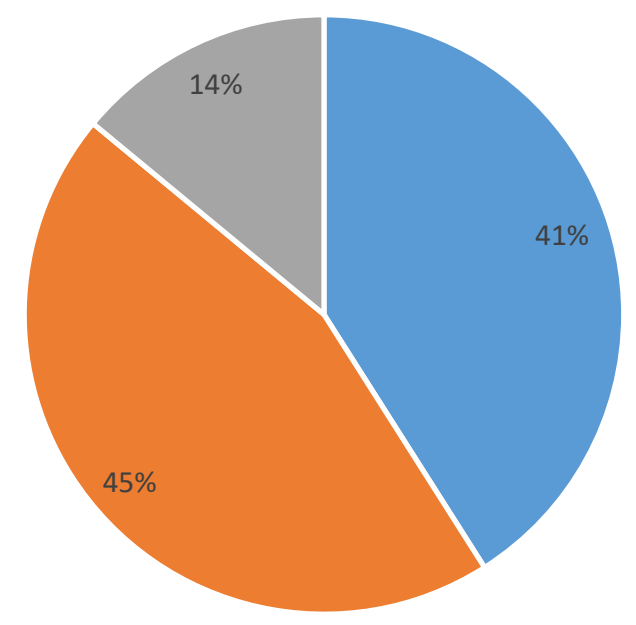

- basic textbook, as it would be in the classroom

- relevant materials from the Internet

- materials prepared by the teacher for your group

Question 11: To what extent do you lack online materials for learning Russian as a Foreign Language?

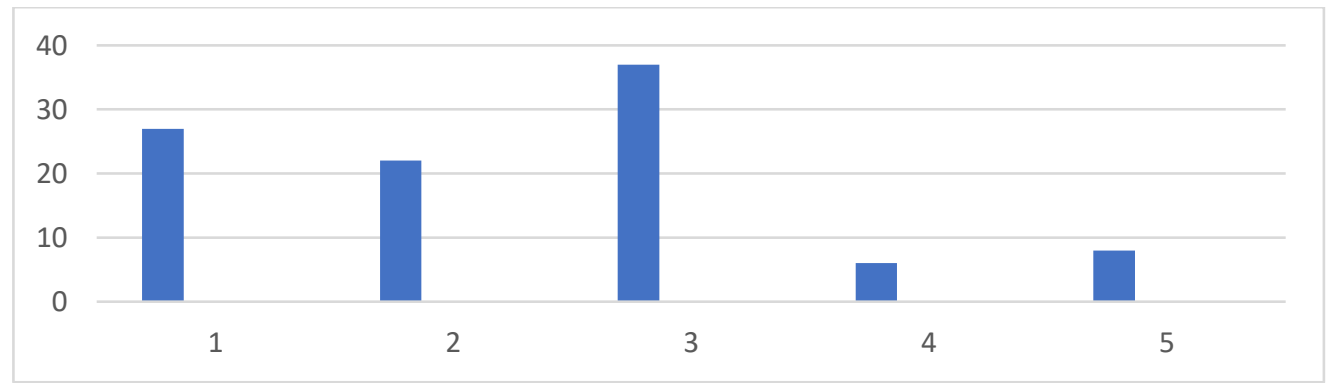


Question 12: How severely does your computer lack the technical capabilities necessary for an online lesson?

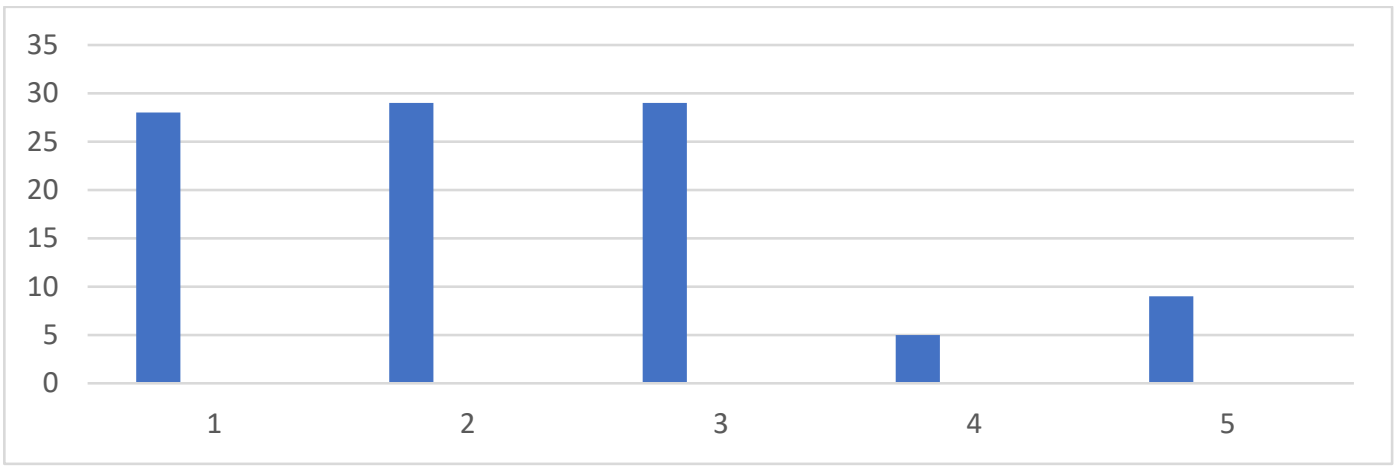

Question 13. How much do you miss the usual forms of learning in an online lesson (board work, working in pairs, game tasks)?

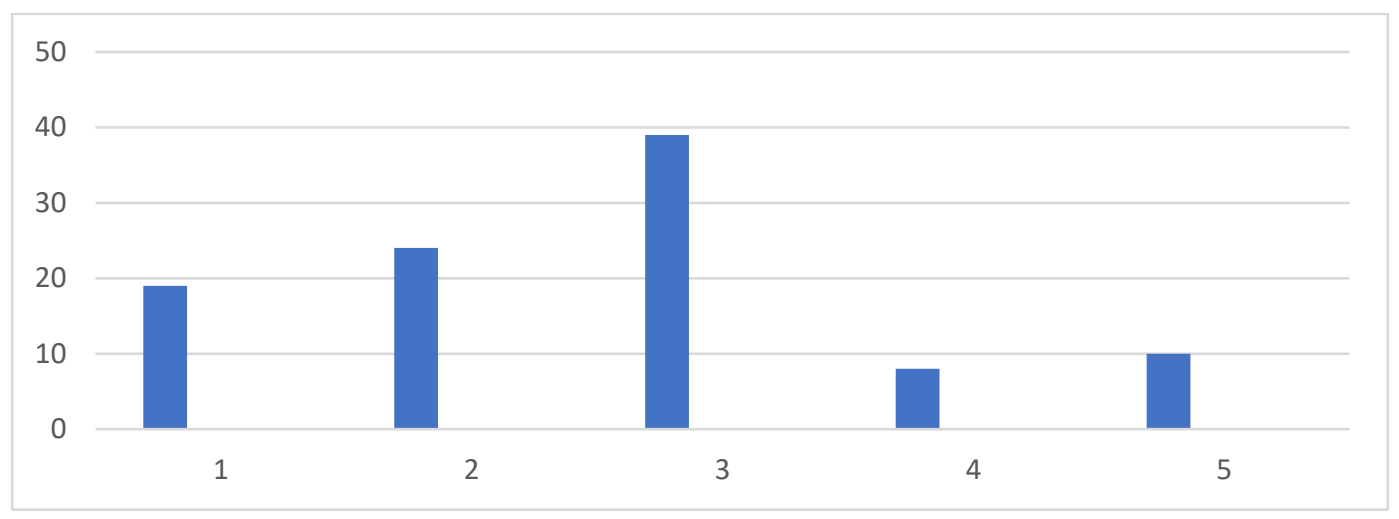

Question 14. How much emotional drive do you lack in the online lesson?

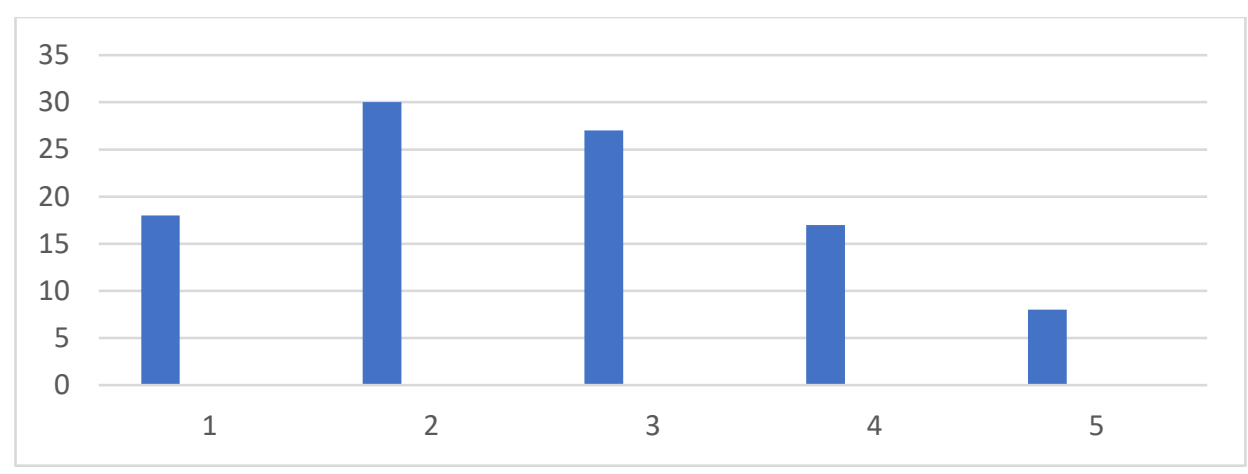

Question 15. How much self-discipline do you lack in an online lesson?

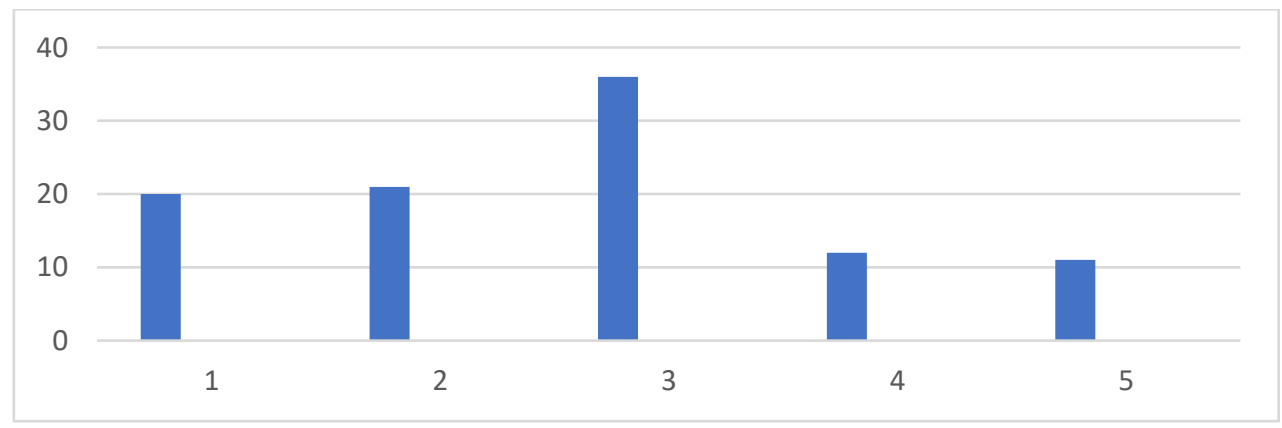


Question 16: What level group do you study in?

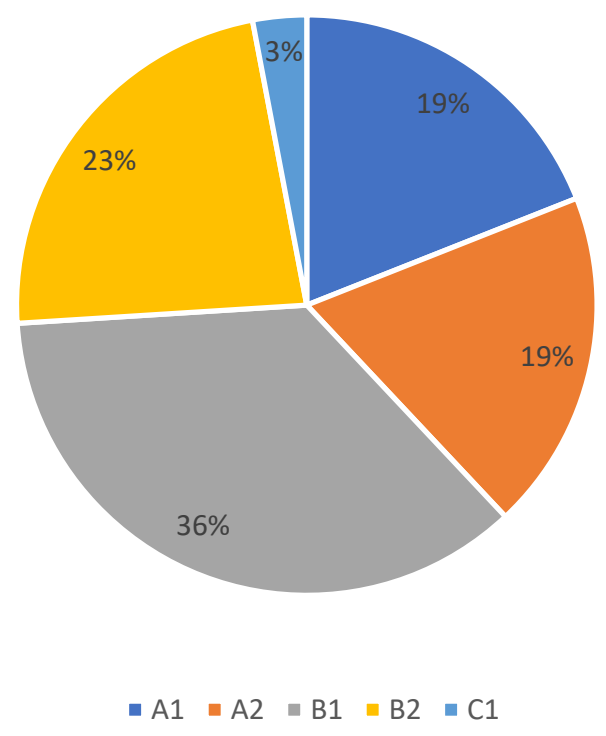

